\title{
THE PERFORMANCE OF THE INDONESIAN NATIONAL AMIL ZAKAT BOARD IN SUPPORTING THE DEVELOPMENT OF HEALTHY SANITATION IN KARANGANYAR, CENTRAL JAVA
}

\author{
Samsi, Darsono, Suprapti Supardi, Sapja Anantanyu \\ Doctoral Program in Community Empowerment, Universitas Sebelas Maret
}

\begin{abstract}
Background: Indonesia faces some major challenges, including increasing poverty and income inequality. Islam has provided guidance for humans to contribute some of their income and wealth in the forms ofzakat, donation, and charity, to the poor and disadvantaged segment of the population. The fund collected can be sizeable as the majority of Indonesians are Moslem.The Indonesian government has established a special agency, namely Indonesian National Amil Zakat Board (BAZNAS), to manage the fund. The institute is supported by the state budget funds and managed by the government officials. The district government of Karanganyar, Central Java, has initiated to use this fund to address priority local health problems, particularly the poor sanitation and poor personal hygiene of the community associated with the increasing risk of diarrheal disease. The poor sanitation can have some negative impacts on various aspects of human life, including worsening quality of environment, polluted drinking water for the community, increasing incidence of infectious diseases, increasing incidence of stunting in children, and disgraced image of the district. This study aimed to examine the performance of BAZNAS in implementing sanitation program to address poor sanitation problems in Karanganyar, Central Java.

Subjects and Method: This was a descriptive qualitative study conducted in Karanganyar, Central Java. The key informants were some officials at the district government, including head of Karanganyar district BAZNAS. The data were collected by in-depth interview, focus group discussion, and document review. Results: Karanganyar district BAZNAS has disbursed its fund to support some health development programs, including waste management, drilling well construction, hygienic latrine supply, and the development of 1000 septic tank evacuation per annum program. All these BAZNAS-supported health development programs conform and synergize with the Karanganyar district overall development policy and masterplan. BAZNAS has successfully empowered the local communities by socializing the "Stop Open Defecation" campaign ("stop BABS").

Conclusion: Broadly speaking, Karanganyar district BAZNAS has shown good performance by allocating its fund to support health and sanitation development. It also has encouraged and boosted the local community involvement in the local health development.
\end{abstract}

Keywords: BAZNAS, performance, local government, policy, sanitation, health development

Correspondence:

Samsi. Doctoral Program in Community Empowerment, Universitas Sebelas Maret, Jl. Ir. Sutami No. 36 A, 57126, Surakarta, Central Java. 